\title{
The effect of Problem and Learning Motivation Based Learning Model on Student's Critical Thinking Skills in SD Negeri 104217 Sidomulyo
}

\author{
Eli Amos Tarigan', Dian Armanto², Mulyono² \\ ${ }^{1}$ Student of Pascasarjana Universitas Negeri Medan, Indonesia \\ ${ }^{2}$ Lecturer in Universitas Negeri Medan, Indonesia \\ tarigan824@gmail.com
}

\begin{abstract}
This study is aimed to determine: (1) whether the critical thinking skills of students taught with problem-based learning models are higher than the critical thinking skills of students taught with Direct Instruction learning models, (2) whether the critical thinking skills of students who have higher learning motivation are more higher than the critical thinking skills of students who have low learning motivation; and (3) the interaction between learning models and learning motivation on student's critical thinking skill. The population in this study were all fifth grade students of SD Negeri 104217 Sidomulyo, consisting of 2 classes with totaling 62 people. The research method used were Quasi Experiment with $2 \times 2$ factorial research design and a significance level of 0.05. The instruments used were motivation questionnaire and critical thinking skills test. Data analysis used were analysis of variance and the Tuckey test. The results showed that: (1) student's critical thinking skills taught with problem-based learning models was higher than the critical thinking skills taught with direct instruction learning models in fifth grade of SD Negeri 104217 Sidomulyo. (2) Student's critical thinking skills who have high motivation was higher than student's critical thinking skills who have low learning motivation fifth grade of SD Negeri 104217 Sidomulyo. (3) There was an interaction between the problem and learning motivation based learning model on the critical thinking skills of students in fifth grade of SD Negeri 104217 Sidomulyo. The strongest interaction that affects critical thinking skills is the highly motivated PBM model, while the weakest interaction is the low motivated direct instruction model.
\end{abstract}

Keywords: Teacher competency; learning media; interest in learning of critical thinking skills; learning motivation; problem based learning.

\section{Introduction}

The goal of Indonesia's national education is to succeed students in all subjects. But in reality, many people view mathematics as the most difficult field of study. Nevertheless, everyone must learn mathematics because it is a means to solve problems in everyday life. Mathematics is an abstract science that focuses on the thought process rather than learning outcomes. As we can see in the process of learning mathematics, a teacher always gives examples of easy questions at the beginning of learning, then the teacher gives difficult questions to the practice questions at the end of learning. This is done so that students who participate in learning experience a process of thinking in working on difficult problems. In other words, it can be said that the mathematical function in human life is to humanize humans themselves by guiding humans to think.

The ability to think is needed in the learning process, the purpose of the learning process is the achievement of learning objectives properly. The achievement of learning objectives can be seen from the learning outcomes obtained after the learning process. Tawil and Liliasari (2013: 4) suggest that "thinking is a cognitive process, a mental activity to gain knowledge. Ennis (in Hassoubah 2004: 86) argues that "critical thinking is thinking reasoned and reflective by emphasizing decision making about what to believe or do". In other words the ability to 
think critically is a deep thought process in analyzing problems or information obtained from the results of interactions with everything in the environment and looking for conclusions and solutions to these problems.

Based on the results of PISA survey from 2000 to 2012 it can be seen that mathematics scores always get the lowest rank compared to science scores. In 2012, Indonesian Mathematics scores ranked second from the bottom with a total number of study participants totaling 65 countries participating in PISA. The low student learning outcomes in mathematics can be caused by, among others, the large amount of test material stated in PISA not in the Indonesian curriculum

Based on observations, it can be concluded that students have difficulty in focusing questions and analyzing problems, so that students misinterpret the problem and problem solving becomes inappropriate. The problem that occurs in these students is due to the low ability of students to think deeply in analyzing the problem stories provided by researchers so that both students produce incorrect answers. Thus it can be said that the critical thinking skills of students is still relatively low. From 30 students of fifth grade of a class SD Negeri 104217 Sidomulyo, only 6 students or around $20 \%$ answered correctly, 19 people or around $63.33 \%$ answered incorrectly, and 5 people or around $16.67 \%$ students did not answer at all. This shows that the critical thinking skills of students in the class is still relatively low. Someone who has low critical thinking skills tends to be wrong in making decisions on the problems they face. Just like the student who made the wrong decision in solving the problem given by the teacher caused by the low critical thinking skills of the student.

The reason for the low of students' critical thinking skills is that the mathematics learning process that has been taking place so far emphasizes more on the aspects of knowledge and understanding, while the application, analysis and evaluation aspects are only a small part of the learning done. That is because during learning takes place in fifth grade of SD Negeri 104217 Sidomulyo, the learning process is carried out with a direct teaching model, which places the teacher as the center of learning. This is due to the lack of teacher mastery of various learning models.

\section{Review of Literature}

\subsection{Problem Based Learning Model}

Problem based learning model is a learning model that uses problems related to the daily lives of students in the learning process to achieve the objectives of the learning. Sani (2014: 127) argues that problem based learning is learning whose delivery is done by presenting a problem, asking questions, facilitating investigations, and opening dialogue. Similarly, Duch (in Shoimin, 2014: 130) argues that problem based learning (PBL) is a teaching model characterized by real problems as a context for students learning to think critically and problem solving skills and gain knowledge. In other words, using a problem based learning model will encourage students to think critically and solve problems to gain knowledge. Following is the syntax of problem based learning

Table 1. Syntax of Problem Based Learning

\begin{tabular}{|c|l|}
\hline Learning Stages & \multicolumn{1}{c|}{ Teacher's Activity } \\
\hline $\begin{array}{c}\text { Stage 1 } \\
\text { Student orientation to the problem }\end{array}$ & $\begin{array}{l}\text { The teacher explains the learning objectives, } \\
\text { explains the logistics needed, motivates students to } \\
\text { engage in problem solving activities, and proposes } \\
\text { problems. }\end{array}$ \\
\hline
\end{tabular}




\begin{tabular}{|c|l|}
\hline $\begin{array}{c}\text { Stage 2 } \\
\text { Organizing the students }\end{array}$ & $\begin{array}{l}\text { At this stage the teacher divides students into groups, } \\
\text { helping students define and organize learning tasks } \\
\text { related to problems. }\end{array}$ \\
\hline $\begin{array}{c}\text { Stage 3 } \\
\text { Guide individual and group } \\
\text { investigations }\end{array}$ & $\begin{array}{l}\text { The teacher encourages students to gather } \\
\text { information needed, carry out experiments and } \\
\text { investigations to get explanations and problem } \\
\text { solving. }\end{array}$ \\
\hline $\begin{array}{c}\text { Stage 4 } \\
\text { Develop and present the work }\end{array}$ & $\begin{array}{l}\text { The teacher helps students in planning and } \\
\text { completing reports, documentation, or models, and } \\
\text { helps them share assignments with their peers. }\end{array}$ \\
\hline $\begin{array}{c}\text { Stage 5 } \\
\text { Analyze and evaluate the process } \\
\text { and results of problem solving }\end{array}$ & $\begin{array}{l}\text { The teacher helps students to reflect or evaluate the } \\
\text { process and the results of their investigations. }\end{array}$ \\
\hline
\end{tabular}

Based on these opinions, it can be concluded that the problem-based learning model is a teaching framework that presents contextual problems at the beginning of learning related to the material to be studied which refers to five phases, namely the orientation of students to the problem, organizing students, guiding individual or group investigations, developing and presenting work, and analyzing and evaluating problem solving processes and results.

\subsection{Learning Model of Direct Instruction}

Direct instructional learning model or better known as direct teaching is a learning model that is teacher center. So that in learning like this the learning process is centered on the teacher, in other words the teacher is more active in the learning process than the student. Arends (in Trianto, 20011: 41) says that direct teaching is one of the teaching models specifically designed to support student learning processes related to declarative knowledge and well-structured procedural knowledge that can be taught with a pattern of gradual, stepby-step activities . Kardi and Nur (in Trianto, 2011: 41) suggested several characteristics of the direct instruction learning model, there are: 1) the existence of learning objectives and the effect of the model on students including learning assessment procedures. 2) The syntax or overall pattern and flow of learning activities. 3) The management system and learning environment model needed for certain learning activities to take place properly. The following is the syntax of the direct learning model according to Kardi and Nur (in Trianto, 2011: 43).

Table 2. Syntax of the Direct Instruction Learning Model

\begin{tabular}{|c|l|}
\hline Phase & \multicolumn{1}{c|}{ Teacher's Role } \\
\hline $\begin{array}{c}\text { Phase 1 } \\
\text { Delivering learning objectives and } \\
\text { preparing students }\end{array}$ & $\begin{array}{l}\text { Gruru explains the learning objectives, background } \\
\text { information, the importance of the lesson, preparing } \\
\text { students to learn. }\end{array}$ \\
\hline $\begin{array}{c}\text { Phase 2 } \\
\text { Demonstrating knowledge and } \\
\text { skills }\end{array}$ & $\begin{array}{l}\text { The teacher demonstrates skills correctly, or presents } \\
\text { information step by step }\end{array}$ \\
\hline $\begin{array}{c}\text { Phase 3 } \\
\text { Guiding training }\end{array}$ & $\begin{array}{l}\text { The teacher plans and provides initial training } \\
\text { guidance }\end{array}$ \\
\hline Phase 4 & $\begin{array}{l}\text { Check all students have successfully done the } \\
\text { assignment well, with feedback }\end{array}$ \\
\hline
\end{tabular}




\begin{tabular}{|c|l|}
\hline $\begin{array}{c}\text { Check understanding and provide } \\
\text { feedback }\end{array}$ & \\
\hline $\begin{array}{c}\text { Phase 5 } \\
\begin{array}{c}\text { Provide opportunities for advanced } \\
\text { training and implementation. }\end{array}\end{array}$ & $\begin{array}{l}\text { The teacher prepares opportunities for further } \\
\text { training, with special attention to applying to more } \\
\text { complex situations and everyday life. }\end{array}$ \\
\hline
\end{tabular}

Based on the description above, it can be concluded that the direct instructional learning model is a teaching framework dominated by teachers that refers to the five syntaxes that is conveying learning objectives and preparing students, demonstrating knowledge and skills, guiding training, checking understanding and providing feedback, and providing opportunities for advanced training and application.

\subsection{Learning Motivation}

According to Hoy and Miskel (in Purwanto 2010: 72) said motivation can be defined as complex forces, impulses, needs, statements of tension (tension states), or other mechanisms that initiate and maintain activities that desirable towards the achievement of personal goals. Santrock (2011: 199) says motivation involves processes that provide energy, direction and maintain behavior. Thus motivated behavior is behavior that contains energy, directed, and can be maintained.

According to Donald (in Sardiman 2009: 73) motivation is a change in energy in a person which is marked by the appearance of 'feeling' and preceded by a response to the existence of goals". From this understanding it can be said that with motivation there can be changes in energy in humans. In other words motivation is very important for human life in living their lives. Uno (2014: 23) says that learning motivation is internal and external encouragement to students who are learning to make changes in behavior in general with several supporting indicators.

Based on the description above, it can be concluded that learning motivation is a condition that makes a person have a desire or encouragement from inside and outside himself in carrying out the learning process to achieve the needs or learning objectives that can be measured through tenacious indicators in the face of difficulties, persevering in facing tasks, have an interest in learning, learn independently, get bored quickly on routine tasks, be able to defend opinions, it is not easy to let go of things that are believed to be truthfully rational and happy in facing challenges.

\section{4. Critical Thinking Skills}

Scriven (in Fisher, 2008: 10) argues that critical thinking is a skillful and active interpretation and evaluation of observation and communication, information and argumentation. Tawil and Liliasari (2013: 7) argued that critical thinking is a disciplined process that is intellectually active and skillfully conceptualizes, applies, analyzes, synthesizes, and or evaluates information collected from or produced by, observation, experience, reflection, reasoning or communication, as a guide for trust and action. In line with this Paul (in, Tawil and Liliasari 2013: 8) views critical thinking as an intelligent disciplinary process of conceptualization, application, analysis, synthesis and evaluation of active and skilled skills that are collected from, or produced from observations. Thus it can be said that the critical thinking of mathematics is the skills of students to use reasoning to understand and analyze 
problems related to mathematics and students' daily lives, as well as looking for and considering solutions or answers to these problems.

Based on the opinions of the experts above, it can be concluded that the ability to think critically is the process of thinking deeply about the problems faced that aim to believe or do something in considering and evaluating information and making decisions or solutions to problems that can be measured with indicators focusing questions, analyzing arguments, answering opposing questions, and making and considering the results of decisions.

\section{Research Method}

This research method used was quantitative approach with quasi experimental type with $2 \times 2$ factorial research design. This research was conducted at SD Negeri 104217 Sidomulyo, Biru-Biru Subdistrict, Deli Serdang District, North Sumatra Province. The population in this study were all fifth grade students of SD Negeri 104217 Sidomulyo, consisting of 2 classes totaling 62 students, including fifth grade of a class consisting of 32 students and fifth grade of b class consisting of 30 students. The sample in this study was from the fifth grade of a class and fifth grade of $b$ class, then the determination for the problem based learning model class and the Direct Instruction class was made by lottery. In Class fifth grade of a class as many as 32 students, and in fifth grade of b class as many as 30 students. Data collection techniques used in this study were student motivation questionnaires and tests of critical thinking skills. The data analysis technique used in this study was inferential statistical techniques. Hypothesis testing is done by two way ANOVA test with a significant level of 0.05 . Before the two-way ANOVA test is performed, first the analysis requirements test is carried out that is the normality test and the data homogeneity test. The normality test was carried out by the KolmogorovSmirnov test while the homogeneity test of the data was carried out by the Levene test with a significance level of 0.05 .

\section{Discussion}

\subsection{Description of Research Data}

a. Pre-Test of Student's Critical Thinking Skills

The pre-test data of student's critical thinking skills in the experimental class and the control class can be seen in the following table.

Table 3. Pre-test Data on Critical Thinking Skills

\begin{tabular}{|c|c|c|c|c|c|}
\hline \multicolumn{3}{|c|}{ Experimentation Class } & \multicolumn{3}{|c|}{ Control class } \\
\hline Interval & $\mathbf{F}$ & Percentage $(\%)$ & Interval & $\mathbf{F}$ & Percentage $(\%)$ \\
\hline $31-40$ & 3 & 9.38 & $31-40$ & 1 & 3.33 \\
\hline $41-50$ & 10 & 31.25 & $41-50$ & 11 & 36.67 \\
\hline $51-60$ & 5 & 15.63 & $51-60$ & 5 & 16.67 \\
\hline $61-70$ & 6 & 18.75 & $61-70$ & 4 & 13.33 \\
\hline $71-80$ & 3 & 9.38 & $71-80$ & 5 & 16.67 \\
\hline $81-90$ & 5 & 15.63 & $81-90$ & 3 & 10.00 \\
\hline $91-100$ & 0 & 0.00 & $91-100$ & 1 & 3.33 \\
\hline Total & 32 & 100.00 & Total & 30 & 100.00 \\
\hline Mean & & 59.38 & Mean & & 60.56 \\
\hline
\end{tabular}


The data in table 3 shows that the critical thinking skills of students in the experimental class and the control class have an average score that is relatively the same as the difference in numbers 1.18 that is in the experimental class by 59.38 and the control class by 60.56 .

\section{b. Post-Test of Student's Critical Thinking Skills}

Post-test data of student's critical thinking skills in the experimental class and the control class can be seen in the following table.

Table 4. Post-test Data on Critical Thinking Skills

\begin{tabular}{|c|c|c|c|c|c|}
\hline \multicolumn{3}{|c|}{ Experimentation Class } & \multicolumn{3}{|c|}{ Control class } \\
\hline Interval & $\mathbf{F}$ & Percentage (\%) & Interval & $\mathbf{F}$ & Percentage (\%) \\
\hline $51-60$ & 0 & 0.00 & $51-60$ & 5 & 16.67 \\
\hline $61-70$ & 3 & 9.38 & $61-70$ & 6 & 20.00 \\
\hline $71-80$ & 5 & 15.63 & $71-80$ & 8 & 26.67 \\
\hline $81-90$ & 11 & 34.38 & $81-90$ & 5 & 16.67 \\
\hline $91-100$ & 13 & 40.63 & $91-100$ & 6 & 20.00 \\
\hline Total & 32 & 100.00 & Total & 30 & 100.00 \\
\hline Mean & \multicolumn{2}{|r|}{85.16} & Mean & \multicolumn{2}{|r|}{76.11} \\
\hline
\end{tabular}

The data in table 4 shows that the critical thinking skills of students in the experimental class and in the control class has a difference in the average score with a difference of 9.05, namely: in the experimental class by 85.16 and in the control class by 76.11 . Thus, it is seen that the average critical thinking skills of students in the experimental class is higher than the control class.

c. Data of Student's Critical Thinking Skills Based on Motivation Level

Description of student's critical thinking skills based on the level of learning motivation is presented in the following table.

Table 5. Grouping the Mathematical KBK Based on Motivation Level

\begin{tabular}{|c|c|c|c|c|c|}
\hline \multicolumn{3}{|c|}{ KBK of High Motivation Students } & \multicolumn{3}{|c|}{ KBK of Low Motivation Students } \\
\hline Interval & $\mathbf{F}$ & Percentage $(\%)$ & Interval & $\mathbf{F}$ & Percentage $(\%)$ \\
\hline $51-60$ & 0 & 0.00 & $51-60$ & 5 & 16.67 \\
\hline $61-70$ & 3 & 9.38 & $61-70$ & 6 & 20.00 \\
\hline $71-80$ & 7 & 21.88 & $71-80$ & 6 & 20.00 \\
\hline $81-90$ & 9 & 28.13 & $81-90$ & 7 & 23.33 \\
\hline $91-100$ & 13 & 40.63 & $91-100$ & 6 & 20.00 \\
\hline Total & 32 & 100.00 & Total & 30 & 100.00 \\
\hline Mean & \multicolumn{2}{|r|}{84.64} & Mean & \multicolumn{2}{|r|}{76.67} \\
\hline
\end{tabular}

The data in table 5 shows that the average of critical thinking skills of students who have high motivation is 84.64 while students who have low motivation is 76.67 . Thus there are differences in the level of students' ability to think based on the level of student motivation. 


\subsection{Hypothesis Test}

Hypothesis test uses two-way ANAVA with a 2x2 factorial design. The calculation is done with the help of SPSS version 23. If the significance of ANAVA (sig.) is smaller than the significance level (0.05), and $\mathrm{F}_{\text {count }}$ is greater than $\mathrm{F}_{\text {table }}$ (4.016) then $\mathrm{H} 0$ is rejected. Hypothesis test results are presented in the following table:

Table 6. Summary of Hypothesis Test Analysis

\begin{tabular}{|c|c|c|c|}
\hline Source & Df & F & Sig, \\
\hline Class & 1 & 12,143 &, 001 \\
\hline Motivation & 1 & 9,341 &, 003 \\
\hline Class * Motivation & 1 & 8,661 &, 005 \\
\hline
\end{tabular}

\section{a. Hipotesis 1}

$$
\begin{aligned}
& \mathrm{H}_{0}: \mu \alpha_{\mathrm{i} 1} \leq \mu \alpha_{\mathrm{i} 2} \\
& \mathrm{H}_{\mathrm{a}}: \mu_{\mathrm{i} 1}>\mu \alpha_{\mathrm{i} 2}
\end{aligned}
$$

Based on the data table 6 shows that the value of sig. 0.001 is smaller than 0.05 , and $F_{\text {count }}$ 12.143 is greater than $\mathrm{F}_{\text {table }} 4.016$ so $\mathrm{H}_{0}$ is rejected. Thus it was concluded that students' critical thinking skills taught with problem-based learning models were higher than students who were taught with the Direct Instruction model. Based on the comparison of the average Critical thinking skills of students it can be concluded that the average score of Critical thinking skills of students who use the problem-based learning model is 85.16 significantly higher than the direct instruction model that is 76.11 .

\section{b. Hipotesis 2}

$$
\begin{aligned}
& \mathrm{H}_{0}: \mu \beta_{\mathrm{j} 1} \leq \mu \beta_{\mathrm{j} 2} \\
& \mathrm{H}_{\mathrm{a}}: \mu \beta_{\mathrm{j} 1}>\mu \beta_{\mathrm{j} 2}
\end{aligned}
$$

Based on the data table 6 shows that the value of sig. 0.003 is smaller than 0.05 , and $F_{\text {count }}$ 9.3341 is greater than $\mathrm{F}_{\text {table }} 4.016$ so $\mathrm{H}_{0}$ is rejected. Thus it was concluded that the critical thinking skills of students who had high motivation were higher than students who had low motivation. Based on the comparison of the average Critical thinking skills of students it can be concluded that the average score of Critical thinking skills of students who have high motivation is 84.64 significantly higher than low motivation which is 76.67 .

\section{c. Hipotesis 3}

$$
\begin{aligned}
& \mathrm{H}_{0}:(\alpha \beta)_{\mathrm{ij}}=0 \\
& \mathrm{H}_{\mathrm{a}}:(\alpha \beta)_{\mathrm{ij}} \neq 0
\end{aligned}
$$

Based on the data in table 6 shows that the value of sig. 0.005 is smaller than 0.05 , and $\mathrm{F}_{\text {count }} 8.661$ is greater than $\mathrm{F}_{\text {table }} 4.016$ so $\mathrm{H}_{0}$ is rejected. Thus it was concluded that there was an interaction between problem based learning models and learning motivation on critical thinking skills. The interaction is presented in the form of a graph of the SPSS results in the following figure. 


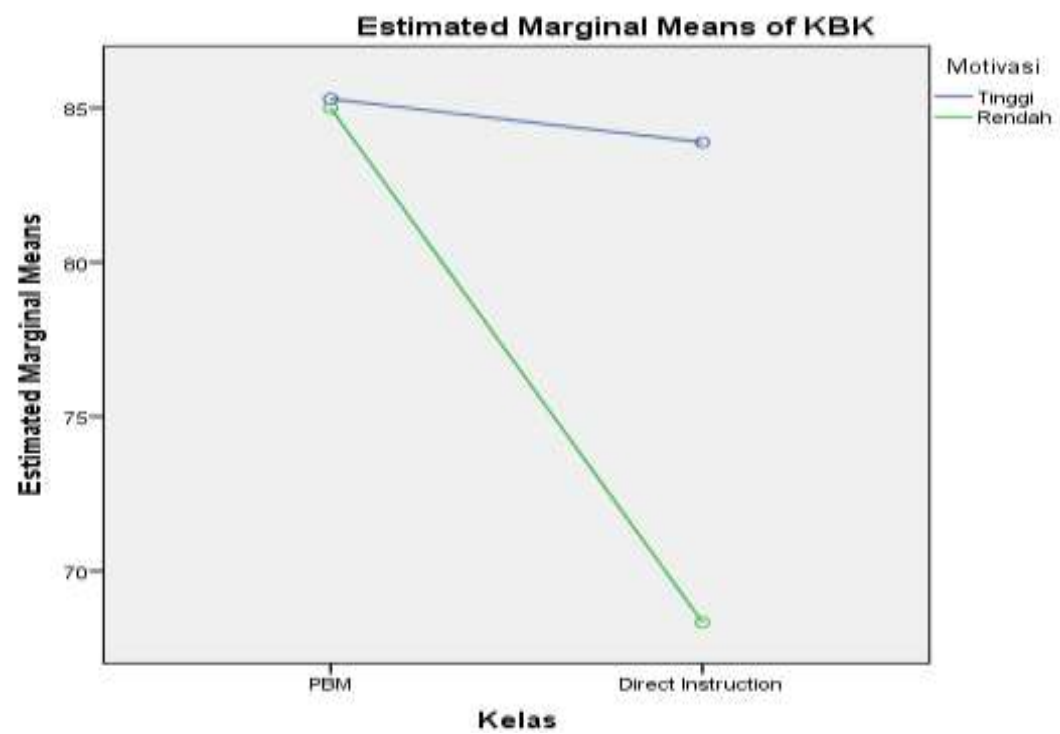

Figure 1. Interaction of Learning Models and Motivation Levels on Critical Thinking Ability

\subsection{Discussion}

The results of this study prove that student's critical thinking skills taught with problembased learning models are higher than students who are taught with direct instruction models. This is based on the results of the first hypothesis test, there are: significance of anava (0.001) is smaller than the significance level (0.05), and $F_{\text {count }}(12.143)$ is greater than $F_{\text {table }}(4.016)$ so $\mathrm{H}_{0}$ is rejected. The test results are also supported by a comparison of the average critical thinking skills, namely: students who use the problem-based learning model (85.16) are higher than the direct instruction model (76.11).

Duch (in Shoimin, 2014: 130) argues that "problem based learning (PBL) is a teaching model characterized by real problems as a context for students learning to think critically and problem solving skills and gain knowledge". Daryanto (2014: 29) suggests that "problem-based learning is a learning model that challenges students to 'learn how to learn', work in groups to find solutions to real-world problems". Ngalimun (2014: 163) suggests that "problem-based learning trains and develops the ability to solve authentic problem-oriented problems from the actual lives of students, to stimulate higher-order thinking skills". The same thing was also stated by Tung (2015: 228) that "problem-based learning is learning that emphasizes authentic problem solving such as problems that occur in everyday life. Thus through the problem based learning model students are guided to solve or find their own solutions or answers to a problem in the learning process, so that students will be involved in learning to solve problems in the real world.

\section{Conclusion}

Based on the results of research and discussion that has been described previously, then some conclusions can be drawn including the following:

1. The critical thinking skills of students taught with problem-based learning models is higher than the critical thinking skills taught with the direct instruction learning model in fifth grade of SD Negeri 104217 Sidomulyo. 
2. The critical thinking skills of students who have high motivation is higher than the critical thinking skills of students who have low learning motivation in fifth grade of SD Negeri 104217 Sidomulyo.

3. There is an interaction between the problem-based learning model and learning motivation on student's critical thinking skills in fifth grade of SD Negeri 104217 Sidomulyo. The strongest interaction that affects critical thinking skills is the highly motivated PBM model, while the weakest interaction is the low motivated direct instruction model.

\section{References}

Fisher, Alec. 2008. Berpikir Kritis Sebuah Pengantar. Jakarta: Erlangga.

Hassoubah, Zaleha Izhab. 2004. Developing Creative Critical Thingking Skills: Cara Berpikir Kreatif dan Kritis. Bandung: Yayasan Nuansa Cendekia.

Purwanto, M. Ngalim. 2010. Psikologi Pendidikan. Bandung: PT Remaja Rosdakarya.

Sani, Berlin dan Kurniasih, Imas. 2015. Ragam Pengembangan Model Pembelajaran: untuk Peningkatan Profesionalitas Guru. Yogyakarta: Kata Pena.

Santrock, J. W. 2011. Psikologi Pendidikan Educational Psychology. Jakarta: Salemba Humanika.

Sardiman. A. M. 2009. Interaksi dan Motivasi Belajar Mengajar. Jakarta: Raja Grafindo Persada.

Shoimin, Aris. 2014. 68 Model Pembelajaran Inovatif dalam Kurikulum 2013. Yogyakarta: Ar-Ruzz Media.

Tawil, Muh dan Liliasari. 2013. Berpikir Kompleks dan Implementasinya dalam Pembelajaran IPA. Makassar: Badan Penerbit UNM.

Trianto. 2011. Mendesai Model Pembelajaran Inovatif-Progresif: Konsep, Landasan, dan Implementasinya pada Kurikulum Tingkat Satuan Pendidikan (KTSP). Jakarta: Kencana.

Uno, Hamzah. B. 2014. Teori Motivasi dan Pengukurannya: Analis di Bidang Pendidikan. Jakarta: Bumi Aksara. 